\title{
OORMATIGE BEVOLKINGSAANWAS EN BEHEER
}

\section{DAARVAN}

EK is baie dankbaar dat $u$, dr. De Vries, deur $u$ uitnodiging om hierdie Predikantekring te kom toespreek, vir my 'n geleentheid gegee het om met $u$ gedagtes te kom wissel oor een van die grootste probleme van ons era - miskien van enige era in die mens se geskiedenis. Laat my slegs toe om te wys dat die wêreldbevolking van 1830 tot 1930 oor honderd jaar homself verdubbel het. Daarna het dit slegs 35 jaar geneem om homself te verdubbel en die volgende verdubbeling kan binne 15 jaar plaasvind. Ek praat dus oor ' $n$ wesenlike probleem. Die V.V.O. bereken dat die huidige bevolking van 3,8 biljoen mense teen 2000 op 8 biljoen te staan mag kom. Dit is dus ' $n$ wêreldprobleem.

\section{'n Aktuele etiese probleem}

Wanneer hierdie saak naamlik die ontsaglik snelle mense-aanwas bespreek word, word die moreel etiese en godsdienstige aspekte daarvan dikwels of totaal geïgnoreer, ò dan slegs heel oppervlakkige aandag aan geskenk. Ek glo egter dat die tyd nou oorryp is dat ook en veral in óns land met sy heterogene bevolking, daar op indringende wyse vanuit 'n Christelike standpunt besin moet word oor die hele aangeleentheid van oormatige bevolkingsaanwas. U, die herders en leraars van ' $n$ belangrike deel van hierdie land se bevolking, u, met $u$ opleiding in die teologie, filosofie en etiek, $u$ moet op onbevange en onbevooroordeelde wyse kennis neem van die feite van die bevolkingsaanwas, hier te lande, in ons buurlande, en in die wêreld in die algemeen. $U$ moet intelligent bespiegel oor die moontlike gevolge van die hoogs komplekse wisselwerking tussen die steeds toenemende aantal mense op ' $n$ eindige aarde en die eindige en beperkte lewens- en bestaansmiddele daarvan wat teen ' $n$ sorgwekkende tempo opgebruik word deur die steeds aangroeiende vloedgolf van mense.

Nou is daar seker ' $n$ mate van regverdiging vir die beskuldiging dat ek my blindstaar teen die getalle en dat ek ' $n$ humanistiese benadering vooropstel. Indien dit so is, wil ek my akademiese agtergrond as gedeeltelike verskoning aanbied: Ek het in die Natuurwetenskappe en daarna in die Geneeskunde studeer en ek het derhalwe nie vir my geroepe gevoel om hierdie saak - oormatige bevolkingsaanwas en die beheer daarvan - op ander as praktiese, of as $u$ wil, humanistiese gronde te benader nie.

Dit is dan my doel om vanoggend aan $u$ weer eens die feite en hulle gevolge soos ek dit sien, te stel, en dan te pleit dat $u$ met $\dot{u}$ akademiese agtergrond die hele saak prinsipieel, moreel-eties en teologies moet verwerk. Want, wát u siening ook al mag wees, een feit staan soos ' $n$ paal bo water: langer kan die harde feite van die hoogs komplekse en inmekaarverstrengelde gevolge van die ontsaglik snelle bevolkingsgroei van ons era nie meer misgekyk word nie 
- ook en veral nie deur u, die geestelike leiers van 'n deel van ons volk nie. Die tyd het aangebreek dat $u$ 'n baie duidelike standpunt oor bevolkingsgroei en die gevolge daarvan moet inneem; dat u dié standpunt luid, waarneembaar en aanhoudend moet stel, vanaf $u$ indiwiduele kansels, maar ook en miskien aanvanklik as 'n standpuntstelling wat geformuleer is in $u$ hoogste kerkvergadering. Het die tyd nie aangebreek nie dat 'n soort van Dordtse Sinode hier in ons land belê word waarop hierdie saak in al sy fasette moet uitgepluis word en waaruit dan duidelike, en uit Gods Woord verantwoorde leiding gegee moet word? Het die tyd nie aangebreek nie dat 'n gesaghebbende geskrif hieroor die lig sien waarin die Christelike standpunt helder en duidelik gestel word?

In vergelyking met die bevolkingsdigtheid ten tyde van Christus se omwandelinge op hierdie wêreld, sal die verwagte bevolkingsdigtheid in die jaar 2000 , byna 3400 keer hoër wees! Kán u in die lig hiervan sowel as van die ander bevolkingslaste nog daaraan twyfel dat die Goddelike opdrag om te vermeerder en die aarde te vul, wat in Gen. 1 : 28 gegee is, nou letterlik uitgevoer is?

Ek gaan dan nou kortliks agtereenvolgens stel: Die getallesituasie in die wêreld, in Suid-Afrika en in Suider Afrika; op enkele gevolge daarvan wys; en my siening oor die benodigde optrede uiteensit. Ek gaan afsluit deur enkele vrae aan $u$ te stel.

Die bevolkingsontploffing en sy gevolge vereis 'n eenheidskonsep 'n Snel-aanwassende bevolking kan vergelyk word met 'n persoon wat 'n ooraktiewe skildklier het; lg. kan soms die gevolg wees van 'n gelokaliseerde kanker. Die simptome van so 'n ooraktiewe skildklier is o.m. gewigsverlies en 'n baie vinnige pols was uiteindelik op hartversaking en die dood sal uitloop. 'n Geneesheer wat so 'n geval sou behandel deur aan die pasiënt 'n vermeerderde voedselinname voor te skryf met die doel om die gewigsverlies te bestry sonder die verwydering van die kwaadaardige gewas, sou onverantwoordelik optree, en behalwe dat hy nie in sy doel sal slaag nie, sou die pasiënt uiteindelik deur die dodelike oorsaak ten gronde gerig word.

So ook is die bevolkingsontploffing die volkskanker wat talle uiters nadelige, selfs dodelike gevolge het, o.m. omgewingsbesoedeling en oormatige gebruik van onvervangbare grondstowwe. Indien besoedeling bv. as losstaande verskynsel gesien en bestry word, sou dit ooreenstem met die bestryding van slegs die gewigsverlies van die persoon met skildklierkanker. Net só futiel soos lg. is, nét so futiel sou die bestryding van die gevolge van die bevolkingsontploffing wees as die oorsaak, naamlik onbeheerde mense-aanwas nie ook terselfdertyd doeltreffend bekamp word nie. Maar, nog meer: Die gevolge van skildklierkanker is veel meer waarneembaar en dramaties as die knoppie in die skildklier wat die oorsaak van die in-die-ooglopende gevolge is. Presies so is die gevolge van die bevolkingsontploffing: besoedeling, verhongering, werkloosheid, gebrek kige onderwysgeriewe, verstedeliking, sosiale euwels ens., ens.; veel meer dramaties en vir groot dele van die bevolking duideliker waar- 
neembaar as die oorsaak nl. geboorte van kinders. Kindergeboortes vind immers in die privaat plaas en kom eintlik net onder die aandag van die kleine familie- en vriendekring.

Ook behoort die bestryding van die gevolg: besoedeling, veel makliker te wees as die bestryding van die oorsaak: oormatige bevolkingsaanwas. Die besoedelde atmosfeer var 'n stad is immers vir al sy inwoners waarneembaar en irriterend, en kragdadige optrede daarteen sal derhalwe die goedkeuring van die inwoners wegdra. Hierteenoor is die bestryding van onbeheerde mense-aanwas veel moeiliker en ingewikkelder aangesien gesinsbeperking hoogs-intieme aspekte van menswees behels, en boonop op wyd-uiteenlopende en emosioneelbelaaide wyse deur verskillende groepe benader word. Die ,behandeling” d.w.s. die aanwending van verskillende voorbehoedmiddels is oneindig minder dramaties en bepaald minder in die ooglopend as bv. die stopsetting van 'n groot fabriek se uitborrelende rookwolke d.m.v. die gebruik van rooklose brandstowwe. En eindelik; suksesvolle beëindiging van besoedeling is onmiddellik, (of dan na 'n relatief kort periode), waarneembaar. Iets wat die bestaan van baie mense versuur het, het opgehou om dit te doen; 'n hele stad se inwoners kan nou spog met „ons skoon lug”; die owerhede kan nou spog met, en selfs politieke voordeel haal uit hulle optrede.

In skerpe teenstelling hiermee is die resultaat van gesinsbeplanning letterlik nie waarneembaar nie - die kinders waarvan die geboorte voorkom is, is immers nie te sien nie! Die gevolge van 'n dramatiese vermindering van geboortes sal slegs oor 'n dekade of veel langer begin manifesteer as daar minder skole gebou moet word en aan alle kinders behoorlik onderwys gegee kan word, as die werkloosheidsyfer daal, as die lewensstandaard begin styg.

Boonop mag regerings ook meen dat grootskaalse propagering van gesinsbeplanning ,dalk vir ons stemme kan kos".

Hierin lê 'n groot gevaar opgesluit: Omdat propagering van besoedelingbestryding minder aanvegbaar is as die propagering van gesinsbeplanning; omdat suksesvolle besoedelingsbestryding waarneembaar is en tot gewilde en snelle resultate lei, terwyl die niewaarneembare geboortebeperkingstegnieke tot 'n nie-in-die-ooglopende afname in kindertalle lei, waarvan die voordele eers in die toekoms gevoel sal word, boonop nog hoofsaaklik deur hulle nakomelinge en nie deur diegene wat tans gesinsbeplanning toepas nie, daarom sal die versoeking baie groot wees om die klem baie sterker te laat val op die meer dramatiese, die meer aanvaarbare besoedelingsbestryding as op die veel moeiliker, ingewikkelder en beslis veral meer prosaiese gesinsbeplanning. Só 'n optrede moet as futiel en dodelik gesien word omdat dit in werklikheid op die behandeling van ' $n$ onplesierige simptoom en die verontagsaming van 'n dodelike oorsaak sal neerkom.

Die aangewese en logiese optrede is dus om die waarneembare gevolge van die bevolkingsontploffing - besoedeling, werkloosheid, gebrekkige onderwys- en gesondheidsgeriewe, en 'n steeds dalende lewenspeil te bekamp. Om hieraan, ook ter wille van politieke gewin, groot prominensie te verleen, is nie te veroordeel nie! Maar, die 
oorsaak, nl. die bevolkingsontploffing moet as oorsaak duidelik en aanhoudend gestel word. Daar moet geen twyfel by die massas gelaat word nie oor die feit dat simptoombestryding sonder oorsaakbestryding futiel is en sekerlik rampspoedig sal eindig.

In die praktyk behoort dus in die R.S.A. langs 'n departement of ministerie van besoedelingsbestryding en omgewingsbeskerming ook 'n volskaalse ministerie van gesinswelsyn in aansien geroep te word om as koördinerende instansie op te tree tussen 'n hele aantal bestaande instansies om ook die oorsaak, naamlik die bevolkingsontploffing deur middel van 'n doeltreffende gesinsbeplanningsprogram te bestry.

MOONTLIKE BEVOLKINGSGROEI IN DIE R.S.A. TOT DIE JAAR 2000 (AMPTELIKE STATISTIEK EN DAAROP GEBASEERDE BEREKENINGE)

\begin{tabular}{|c|c|c|c|c|c|}
\hline 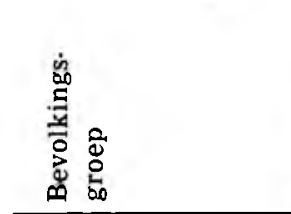 & 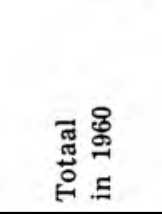 & 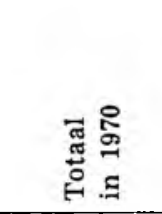 & 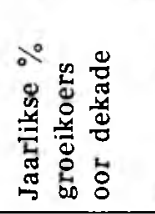 & 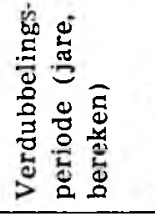 & 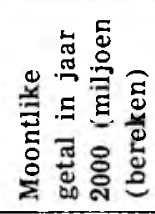 \\
\hline Blankes & 3088492 & 3750716 & 2,14 & $33 / 34$ & 6984 \\
\hline Kleurlinge & 1509258 & 2018533 & 3,37 & $20 / 21$ & 5,496 \\
\hline Asiërs & 477125 & 620422 & 3,00 & $22 / 23$ & 1501 \\
\hline Bantoes (tot.) & 10927922 & 15057559 & 3,78 & $19 / 20$ & $\begin{array}{l}45800 \\
54867^{* *}\end{array}$ \\
\hline Zoeloe & 2863834 & 4026082 & 4,06 & $17 / 18$ & 1339 \\
\hline Xhosa & 3063177 & 3929922 & 2,83 & $25 / 26$ & 8941 \\
\hline Tswana & 1149289 & 1718508 & 4,95 & $14 / 15$ & 7433 \\
\hline Sepedi & 956874 & 1603530 & $6,75^{*}$ & $9 / 10$ & 11570 \\
\hline Seshoeshoe & 1291311 & 1453354 & $\begin{array}{l}4,1^{* * *} \\
1,26^{* * *}\end{array}$ & $\begin{array}{l}65 / 66 \\
17 / 18^{* * * k}\end{array}$ & $\begin{array}{c}212 \\
4,834^{* * *}\end{array}$ \\
\hline Shangaan & 506701 & 736978 & 4,54 & $16 / 17$ & 2757 \\
\hline Swazi & 338528 & 498704 & 4,73 & $15 / 16$ & 1972 \\
\hline Venda & 242149 & 357875 & 4,8 & $15 / 16$ & 1455 \\
\hline Ndebele (N.\& S.) & 290590 & 414641 & 4,27 & $16 / 17$ & 1,457 \\
\hline Ander & 225469 & 317965 & 4,10 & $17 / 18$ & 1058 \\
\hline Tot. bevolking & 16002792 & 21447230 & 3,40 & $20 / 21$ & $\begin{array}{l}68848 \\
5839^{* *}\end{array}$ \\
\hline
\end{tabular}

* Hierdie groeikoers is die hoogste, tans bekende ter wêreld.

** Die syfer 54867 is verkry deur die individuele Bantoe-volksgroepe se groeikoerse te gebruik; as alle Bantoes se gemiddelde groeikoerse van $3,78 \%$ gebruik word, word 'n syfer van 45800 miljoen verkry. Die onderskeie totale word dan 68848 miljoen en 5839 miljoen.

*** Hoewel die groeikoers van die Seshoeshoe amptelik as $1,26 \%$ angegee is, is hierdie getal só 'n uitsondering op die reël dat die groeikoers van die periode $1951-1960 \mathrm{nl}$. $4.1 \%$ wat hulle toe gehandhaaf het, vir die berekening gebruik is. 

word is:

Die vernaamste afleidings wat uit hierdie tabel gemaak kan

(a) Die totale bevolkingsgetalle van 1970 (21 45 miljoen), kan meer as drievoudig toeneem gedurende die laaste drie dekades van hierdie eeu.

(b) Die Blankes sal hulle 1970-getal nie eers teen daardie tyd verdubbel het nie. Hierteenoor sal die Bantoes se 1506 miljoen van 1970 met ' $n$ faktor van 364 kan toeneem tot 54867 miljoen.

(c) Die 6984 miljoen Blankes sal in die jaar 2000 sowat $10 \%$ van die totale Suid-Afrikaanse bevolking kan uitmaak.

(d) In 1970 was van die sowat 15 miljoen Bantoes, 7 miljoen in die Tuislande en 8 miljoen in die Blanke gebiede woonagtig. Indien die 1970-verdeling van Bantoes tussen Tuislande en Blanke-gebiede vorentoe presies onveranderd bly, d.w.s. die beleid van Tuislandontwikkeling met die daarmee gepaardgaande emigrasie van Bantoes uit die Blankegebiede na die Tuislande totaal misluk, dan sal $7 / 15$ van 54867 miljoen oftewel 25606 miljoen Bantoes in 2000 in die Tuislande en 29264 miljoen in die Blanke gebiede woon. Word daar egter aangeneem dat minstens die helfte van die verwagte aanwas van die Bantoes in die Blanke gebiede na die Tuislande sal emigreer en dat min of geen immigrasie vanuit die Tuislandgebiede na die Blanke gebiede sal plaasvind nie, kan sowat 40 miljoen Bantoes hulle in die jaar 2000 in die Tuislande bevind. In eersgenoemde geval sou die 1970 Bantoetalle, nl. 7 miljoen in die Tuislande met ' $n$ faktor van sowat 3,6 , en in laasgenoemde geval met 'n faktor van sowat 5,7 toegeneem het.

Die omvang van die politieke, sosiale en ekonomiese gevolge wat uit 'n drie tot sesvoudige toename van mensemassas oor 'n korte 30 jaar in die huidige onderontwikkelde Tuislandgebiede moet voortspruit kan nie presies voorspel word nie. Gesien in die lig van die aandrang op meer grondgebied wat verskeie Tuislandleiers nou reeds maak, kan met veiligheid aangeneem word dat hierdie land voor uiters ernstige sosio-politieke verhoudingsprobleme te staan gaan kom a.g.v. die huidige geweldige hoë groeikoerse van veral die Bantoes.

Die syfers in die tabel berus op die aanname dat die Bantoes se groeikoerse van die dekade 1960/1970 gehandhaaf sal bly. Dat hierdie aanname oor-optimisties is blyk onder meer uit die volgende:

(a) Volgens amptelike statistiek was $59 \%$ van alle Bantoes in die Tuislande in 1970, 19 jaar en jonger. Die ooreenstemmende syfer in die Blanke gebiede was $48 \%$; en van alle Bantoes in die R.S.A. was $53 \%, 19$ jaar en jonger in 1970 . Daar moet dus noodwendig 'n baie aansienlike toename van geboortes in die Tuislande (en elders) plaasvind as hierdie jongmense geleidelik maar toenemend vorentoe begin reproduseer.

(b) Fasiliteite vir gesondheidsorg van Bantoes in die R.S.A. is besig om toe te neem, ook in die Tuislande. Hierdie feit moet uitloop op 'n aansienlike afname van o.a. kindersterftes. ' $n$ Stygende geboortesyfer met ' $n$ dalende sterftesyfer in die Tuislande (en in 'n mindere mate ook in die Blanke gebiede), moet noodwendig op 'n 
toename in die reeds geweldige hoë groeikoers uitloop.

Dis dus duidelik dat die reeds sombere bevolkingsverhaal wat die tabel se syfers vertel inderdaad sorgwekkend is. 'n Reuse toename moet eenvoudig binnekort plaasvind in die Bantoes se huidige uiters hoë groeikoerse, groeikoerse wat tans letterlik alreeds die hoogste ter wêreld is.

Die allesoorheersende feit in die R.S.A. is dus hierdie reuse mense-aanwas; die allesoorheersende behoefte word dus vermindering van hierdie geweldige groeikoerse.

Die enigste wyse waarop dit kán geskied is gesinsbeplanning wat uit twee duidelike fasette bestaan:

\section{Dienslewering en motivering}

Dienslewering bestaan o.m. uit die oprigting van klinieke, die opleiding van verpleegsters e.a. vrouehulp om die gesinsbeplanningsdienste op die periferie te lewer, sowel as die verskaffing van die nodige voorbehoedmiddels.

Die geneesheer: bevolkingsverhouding in die R.S.A. is tans naastenby soos volg:

Totale geneeshere tot totale bevolking $1: 2000$ (die beste in Afrika).

Blanke geneeshere tot Blanke bevolking $1: 350$ (die beste ter wêreld ).

Asiër geneeshere tot Asiër bevolking $1: 1200$ (die beste in Afrika).

Kleurling geneeshere tot Kleurling bevolking $1: 19000$.

Bantoe geneeshere tot Bantoe bevolking $1: 100000$ (van die laagste ter wêreld).

Hierteenoor geld dat elke dominee miskien ongeveer 350 mense en die Geref. Kerk vir sy verantwoordelikheid het.

Dis dus duidelik dat daar geen geneeshere is om gesinsbeplanning op die periferie te dra nie. Dit moet noodwendig dus op vrouehulp (verpleegsters e.a.), wat spesiaal daarvoor opgelei is, rus.

Motivering bestaan daarin dat onkundige, selfs bevooroordeelde mensemassas beweeg word tot gebruikmaking van fasiliteite wat vir gesinsbeplanning geskep word. Die oorgrote deel van Suid-Afrika se mense is, wat die bevolkingsontploffing betref, beslis oningelig en selfs bevooroordeeld. Sonder motivering kan nie verwag word dat hierdie mense gesinsbeplanning sal aanwend nie.

Statistieke bewys dat die Bantoe-bevolking in Tuislande vir $60 \%$ of meer jonger as 19 jaar is. In Blanke gebiede is dit selfs meer as $50 \%$ - juis a.g.v. verbeterde mediese dienste. Die betreklike hoë sterftesyfer het onder die mense gedaal - maar voortplanting geskied nog onbeheerd. Die gevolg is dat juis die huidige groep jong mense wat kan en sal voortplant hulleself, hulle mense en die land in ongeluk stort - vgl. die groeikoers van die Sepedi as die hoogste in die wêreld. Dit maak dit gebiedend noodsaaklik dat juis die jongmense ingelig moet word met kennis tot verantwoordelike ouerskap, verantwoordelike bevolkingsgroei ens. in ooreenstemming met ekonomiese e.a. faktore. 
Die baie groot verskeidenheid van volks-, etniese, e.a. subgroepe, maar veral die aanwesigheid van die Blankes (wat bevolkingsaanwas selfs 'n noodlottige politieke speelbal kan maak), maak die reeds geweldige ingewikkelde proses om dié miljoene inwoners van Suid-Afrika met hulle lobola-agtergrond, (wat onvermydelik tot groot gesinsgetalle aanleiding gee), tot gesinsbeperking te beweeg, nog soveel ingewikkelder as in lande met meer homogene bevolkings. Die motiveringstaak in die R.S.A. is derhalwe veel dringender en omvattender as elders. Daar moet verduidelik word dat die lobolastelsel en kinderrykdom in 'n tydperk met hoë sterftes, ander soort ekonomiese en sosiale strukture nie net so in die moderne patroon toegepas kan bly nie - bv. een man met 70 vroue en 'n paar honderd kinders nie.

'n Uitvloeisel van die heterogeniteit van die Suid-Afrikaanse bevolking is dat slegs mense uit die eie groep, dus geen vreemdelinge nie, vir die uiters belangrike taak van motivering vir gesinsbeplanning gebruik kan en moet word. Mens-tot-mens motivering is absoluut onontbeerlik onder Suid-Afrikaanse omstandighede.

Geskikte mense sal dus vir hierdie doel letterlik in hulle honderdtalle gevind, gewerf en toegerus moet word om hul eie mense te gaan motiveer, ook en veral in ons eie Tuislande.

Die ,toerusting" sal daarin bestaan dat hulle opgelei sal moet word om motivering te onderneem, sowel as voorsien moet word van motiveringsmateriaal wat 'n lokale kleur sal moet dra.

Die Suid-Afrikaanse Tuislande, (wat eerlang gaan onafhanklik word), beskik natuurlik hoegenaamd nie oor enige fasiliteite vir bogenoemde opleiding nie, nog minder oor die fasiliteite vir die skepping van motiveringsmateriaal, (boeke, films, radiopraatjies, skyfies, ens. ens.) nie; en bepaald nie oor voldoende fasiliteite vir dienslewering nie.

Uit bostaande is dit derhalwe duidelik dat die skepping van 'n gesinsbeplanningsprogram, dienslewering en motivering, tans van die heel dringendste sake in hierdie land is, veral in die Tuislande.

Dat so 'n omvangryke taak alleen deur die landsowerheid onderneem kan word, is voor-die-hand-liggend; eweneens die feit dat die diens deur 'n groot verskeidenheid van bestaande staats-, semi-staats-, en privaat-instansies gelewer sal moet word. 'n Koördinerende instansie, beklee met die hoogste staatsgesag, is hiervoor onontbeerlik.

\section{Vrae aan die teoloë en predikante}

En nou gaan ek 'n uiters gewaagde ding doen: As algehele leek op die gebied van die teologie gaan ek vir u, teologies geskoolde manne, enkele vrae stel na aanleiding van 'n paar Bybeltekste wat ek vir $\mathrm{u}$ gaan voorlees. Miskien openbaar ek my onkunde juis daardeur dat ek losstaande tekste, moontlik heeltemal buite verband met mekaar aan u gaan voorhou vir u kommentaar:

Hebreërs 1:2: U sal my dit tog seker gewonne gee as ek beweer dat een van die uitstaande gevolge van die oormatige menseaanwas 'n steeds toenemende druk op die natuur en sy belangrike hulpbronne is. Die onooglike verinnewering van die aardkors deur 
erosie wat volg op die uitkap van woude vir papier e.a. nywerheidsprodukte; veldbrande, primitiewe landboupraktyke, oorbeweiding en oorbewerking van ongeskikte landbougrond, om van besoedeling van lug, riviere, mere ja, selfs die grote oseane maar te swyg, ek sê dis tog seker die direkte uitvloeisel van die toenemende behoefte aan bestaansmiddele van 'n steeds toenemende mensemassa, dan nie? Meen u nie dat die wyse waarop die mense die steeds vollerwordende erfdeel van die Seun van die Mens besoedel en verinneweer 'n gruwelike sonde in die oë van die Vader is nie?

Genesis 1: 26 en 27: Een van die mees tragiese gevolge van die bevolkingsontploffing is verstedeliking. Die volgende beskrywing van agterbuurtes is deur Paul Ehrlich in „Population Bomb” gegee nadat hy een aand verdwaal en in Niew Delhi se krotbuurt beland het:

„Movement was almost impossible through the streets filled to overflowing with teeming and milling humanity.

People were talking.

People were shouting.

People were fighting.

People were preparing there food and eating.

People were trying to sleep.

People were urinating.

People were defaecating.

People were copulating.

Prior to that mighty journey through those terribly crowded streets of a vast asian slum I had an intellectual grasp of the population explosion; it took that journey to give me an emotional grasp of the terrible scourge of uncontrolled human proliferation."

En nou, dink u dat hierdie siels- en liggaamsvernietigende krotbuurtes, waarin steeds meer en meer miljoene mense „wat geskape is na die ewebeeld van die grote God" gaan beland, die milieu is waarin Sy skepsele kan groei en tot menswaardige wasdom kom en in godvrugtigheid gedy? (1 Kor. 6 : 19; Rom. $12: 1$ ).

Dink u dat krotbuurtes gehoorsame volgelinge vir Christus kweek of stem u met my saam dat krotbuurtes die teelaarde is van die ergste denkbare menslike verwording? Hou permissiwiteit, dwelmverslawing en al die ander sosiale en politieke patologiese uitwasse van ons tyd dan nie ook verband met die onmenslike opeenhoping van Sy skepsele in krotbuurtes nie?

$\mathrm{Ek}$ is die allerlaaste persoon wat sal beweer dat ons hierdie afskuwelikhede nie met alle moontlike middels moet bestry nie ook en veral deur die verkondiging van die Evangelie. Maar nou moet $\mathbf{u}$ my tog nie gaan kwalik neem as ek gaan beweer dat die tempo van mensesamedromming in krotbuurtes reeds so snel is en vorentoe sodanig gaan versnel dat nie meer bygebly kan word met pogings om die verwording te bekamp nie - ook nie deur die prediking van die Woord nie, ook nie in ons land nie. Wat kan ons in 
ons land verwag? In die eerste plek kan daar nie genoeg predikante opgelei word vir die doel nie, en tweedens sou 'n eensydige beskawingspoging (waarby inbegrepe is verkondiging van die Evangelie), 'n bestryding van 'n simptoom wees wat uiteindelik net so nutteloos en futiel sal wees as die bestryding van 'n simptoom van kanker (sê gewigsverlies), sonder 'n gelyktydige behandeling van die kankergewas self. Beskaaf en evangeliseer die krotbuurtbewoner, ja, maar, sien tog ook die volgende logiese noodsaaklikheid raak; voorkom die steeds sneller toenemende ontstaan van krotbuurtes deur paal en perk te stel aan onbeheerde mense-aanwas.

Psalm 111 : 10: Ons tydgewrig se grootste drie onontwarbaar ineengestrengelde feite te wete die bevolkingsontploffing, omgewingsbesoedeling (waarby inbegrepe is besoedeling ook van die mens na liggaam en gees) - en uitputting van onvervangbare grondstowwe stel aan $u$, Christenteoloë en die leiers van Christene, ' $n$ eis wat $u$ nie langer kan ontwyk nie. Hierdie drie dinge moet vanuit 'n Christelike oogpunt bestudeer word, oplossings wat strook met u Christelike gewete moet gevind en deurgevoer word: $U$ wat die Here vrees, $\mathrm{u}$ wat dus 'n goeie verstand het, $\mathrm{u}$ moet die Christelike benadering tot hierdie sake bring - u moet help dink, u moet help oplossings vind, u moet help doen? As Christene mag u nie vir u distansieer van hierdie harde werklikhede nie; u mag nie langer soos die Priester en die Leviet by diégene verbygaan wat $u$ hulp nodig het nie. Alle mense het $u$ hulp nodig, maar meer in die besonder die mense van ons land, ook dié buite die beperkte kring van u gemeentes!

Ek beweer dat $u$ en ek as Christene begunstig is deur die groot Leermeester met kennis en insae in die bevolkingsontploffing en sy euwele gevolge vir siel en liggaam van sovele miljoene wat hierdie insae nie het nie. Ek beweer dat dit ons Christelike plig is om die kousale verband tussen die bevolkingsontploffing en sy dodelike gevolge aan die miljoene van ons oningeligte medemense van SuiderAfrika te verduidelik. Ons is ons broeders se hoeders, ook in hierdie opsig!

Ek beweer ten slotte dat dit ons Christelike plig is om die kennis wat ons het - kennis wat uiteindelik soos alle kennis, Godgegewe is, - dat ons hierdie kennis van gesinsbeheer ook aan ons anderkleurige medemense moet beskikbaarstel om hulle - en ons self te help beskerm teen die selfvernietiging wat die bevolkingsontploffing inderdaad is.

Meen $u$ dat ons as Christene langer gelate mag toesien dat die meer as 50 miljoen anderkleurige mense wat Hy saam met ons in hierdie Suiderland geplaas het hulleself (en ons) deur 'n gebrek aan kennis met hulle ongebreidelde getalsaanwas in die verderf van oorbevolking moet stort?

In die verbygaan vestig ek $\mathrm{u}$ aandag op die boek Birth Control and the Christian (Coverdale House Publishers, London). Van myself het in 1972 by J. L. van Schaik verskyn: Bevolkingsontploffing in Suider-Afrika.

Dr. N. J. van Rensburg.

(Gelewer voor G.T.V. Pretoria, Augustus 1972). 